\title{
The role of executive functions and risk-taking in predicting decision- making styles in university students
}

\author{
Maryam Al-sadat Hosseini ${ }^{1}$, Monir Hosseini ${ }^{2}$ \\ 1-Master of Psychology, Slam-Abad Gharb Branch, Islamic Azad University, Slam-Abad Gharb, Iran. \\ 2- Ph.D in Psychology, Department of Psychology, Kermanshah University of Medical Sciences, Farabi Medical \\ Center, Kermanshah, Iran (Corresponding Author). E-mail: mhossini9859@yahoo.com
}

Received: $12 / 01 / 2020$

Accepted: 12/03/2020

\begin{abstract}
Introduction: Decision-making and the consequences play a key role in the quality of an individual's life, to an extent that it can be asserted that human life is the collective outcome of one's choices and decisions.

Aim: The aim of the present study was to determine the predictive role of the brain's executive functions and risk-taking in the decision-making styles of students.

Method: The research method is a description of the correlation. The statistical population included all students of IAUKSH during the 2019-2020 academic year. Among these students, 240 (male and female) individuals were selected via multi-stage cluster sampling. To collect data, questionnaires of decision-making styles (Scott and Bruce, 1995), rescue executive functions (2013), and risk-taking (Ahmad Pourdariani, 2010) were employed. Data were analyzed by Pearson correlation and systematic regression using SPSS 21 software.

Results: The results revealed that flexibility, programming, memory, and social cognition have the ability to positively and significantly predict students' logical decision-making style $(\mathrm{P}<0.005)$. Among the components of executive functions, only social cognition was a positive and significant predictor of intuitive decision-making style $(\mathrm{P}<0.0001)$. Dependent, immediate, and avoidant decision-making styles had a negative and significant correlation with executive functions. Risk-taking only had the potential to positively and significantly predict students' immediate decision-making style $(\mathrm{P}<0.001)$.

Conclusion: Based on the findings, it can be concluded that different combinations of components of executive functions predict each of the decision-making styles. The basis for this can be considered as different cognitive or emotional processes involved in decision-making.
\end{abstract}

Keywords: Executive functions, Risk-taking, Decision-making styles, Student

How to cite this article : Al-sadat Hosseini M, Hosseini M. The role of executive functions and risk-taking in predicting decision- making styles in university students. Shenakht Journal of Psychology and Psychiatry. 2020; 7 (2): 104-115 .URL: http://shenakht.muk.ac.ir/article-1-739-fa.pdf

Copyright $($ C 2018 the Author (s). Published by Kurdistan University of Medical Sciences. This is an open access article distributed under the terms of the Creative Commons Attribution-Non Commercial License 4.0 (CCBY-NC), where it is permissible to download, share, remix, transform, and buildup the work provided it is properly cited. The work cannot be used commercially without permission from the journal. 


\title{
نقش كار كردهاى اجرايى و ريسكيذيرى در بيشبينى سبك تصميمكيرى دانشجويان
}

\author{
مريم السادات حسينى'، منير حسينى \\ ا. كارشناسى ارشد روانشناسى، واحد اسلام آباد غرب، دانشكاه آزاد اسلامى، اسلام آباد غرب، ايران.

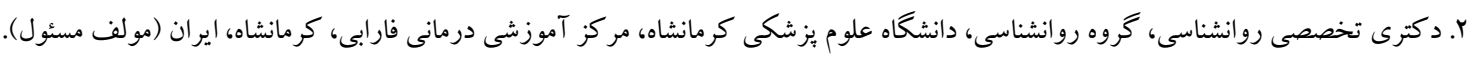 \\ ايميل: mossini9859@yahoo.com
}

مقدمه: تصميم گيرى و بيامدهاى آن نقش كليدى بر كيفيت زندگى انسان دارد، به گونهاى كه مىتوان گفت زندگى انسان ماحصل

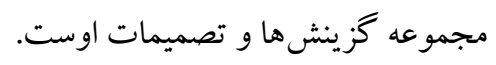
هدف: هدف بزوهش حاضر تعيين نقش بيشبينى كندگى كاركردهاى اجرايى مغز و ريسكيذيرى در سبك هاى تصميم گيرى دانشجويان بود.

روش: طرح يثوهش توصيفى از نوع همبستگى است. جامعه آمارى شامل كليه دانشجويان دانشگاه آزاد كرمانشاه در سال تحصيلى

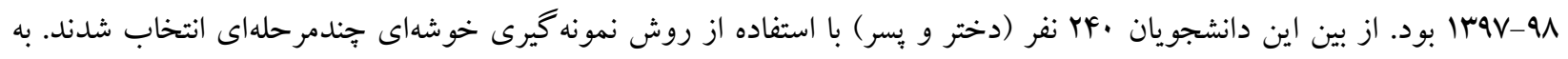

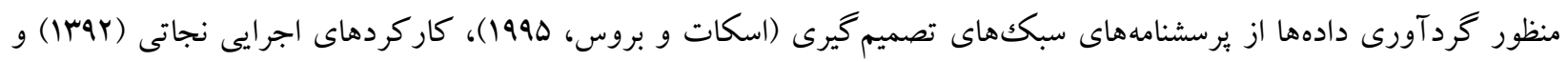

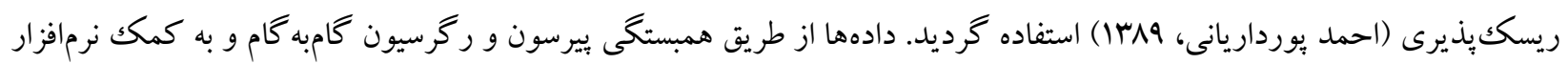
SPSS r I

يافته ها: نتايج يزوهش نشان داد انعطافيذيرى، برنامهريزى، حافظه و شناخت اجتماعى توانايى ويشبينى مثبت و معنادار سبك





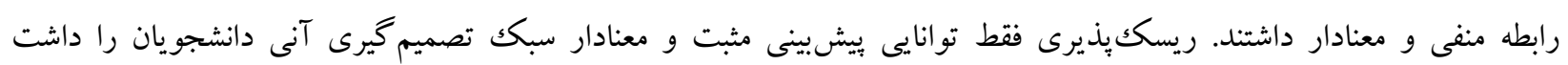

$$
(\mathrm{P}<\bullet / \cdots 1)
$$

نتيجه كيرى: بر اساس يافتهاى حاصله مىتوان نتيجه گُرفت تركيب متفاوتى از مؤلفه هاى كاركردهاى اجرايى هر يكك از سبك هاى تصميم گيرى را ييشبينى مى كنند. دليل اين امر را مىتوان فرايندهاى متفاوت شناختى يا هيجانى دخيل در سبككهاى تصميم گيرى 
فكرى و عملى تصميم كيرنـده و تكيـه بـر حمايـتهـا و

مقدمه

راهنمايىهاى ديخران در هنگام اتخاذ تصميم است.

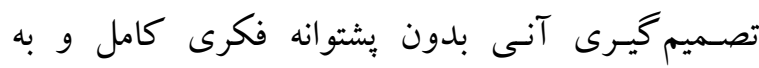

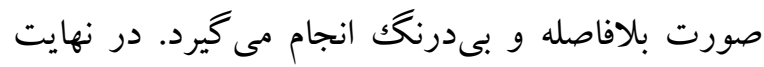
تصميم گيرى اجتنابى، تصميم گيرى به تعويـ افتاده است و در آن فرد از هر گونهه واكسنش نسبت به مسئله رخ داده

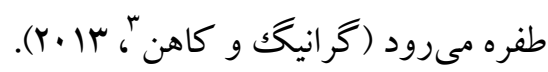
بروين دبروين " و همكاران معتقدند سبك تصميم گيرى غالب در افراد مختلف، با مهارت در تصميم گيرى، مشخصههاى شخصى و توانايىهاى شناختى آنان مرتبط است (عبدى، اسدى، محمديارى و ميرى، وجوا). از جمله توانايىهاى شناختى مؤثر در تصميم گيرى ارزيابى

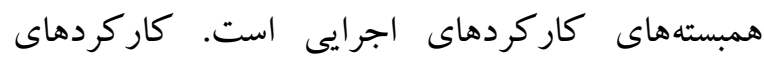
اجرايى توانايىهاى شناختى سطح بالايى همانند توجه، ارزيابى، سازماندهى و انعطاف يذيرى است كه مرتبط با قشر بره فرونتال مغز بوده (ليريسه، 19 19) و براى هدايت

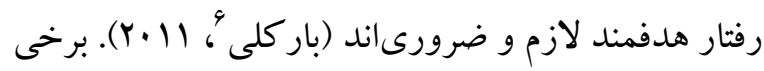
محققين كاركردهاى اجرايى را شاخصى براى "جإگونه)" و


مىداند كه افراد را براى خودگردانى، بازدارى پاسخ نامناسب و برنامهريزى اهداف براى رفتارهاى آينده مدار

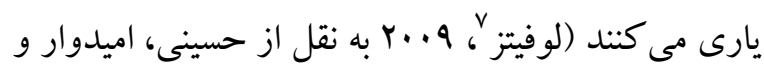
عباسى، و4M 1). كار كردهاى اجرايى مسئوليت بازنگرى و منظم كردن فرآيندهاى شـناختى را در طول انجام

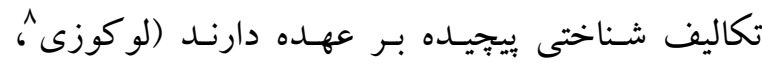
19.19). اعتقاد بر اين است كه برخى از كاركردهاى

\footnotetext{
3.- Grunig \& Kuhn

${ }^{4}$ - Bruine de Bruin

5 - Liris

${ }^{6}$ - Barkley

7- Loftiz

${ }^{8}$ - Locozi
}

1. - Vasilescu
${ }^{2}$ - Scott \& Bruce

تصميم به عنوان عمل دستيابى به نتيجه يا ايجاد فكر و راهحلهاى رسيدن به نتيجه تعريف شده (واسيلسكو'، (Y.11) و تصميم گيرى انتخاب بهترين راهحل از ميان راهحلهاى ممكن است. با آنكه به نظر مىرسد تصميم گيرى فرايندى ساده است اما در واقع يكى از بيجيده ترين و كاه دشوارترين مسائلى است كه فرد با آن مواجه مى گردد. جرا كه تصميم گيرى، گاه انتخاب بين ارزشهاى متعارض است و وبيامدهاى انتخاب يك يك

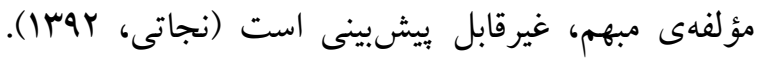
غالباً افراد از راهبردهاى مختلفى براى تصميم گيرى استفاده مى كنند. برخى تصميمات بلهواسطه ارزيابى نظامدار و منظم گزينههاى مختلف اتخاذ مىشود، در حالى كه در اتخاذ تصميمات ديخر تجزيه و تحليل رسمى، كمتر دخالت دارد (جهانبخشى، خوش كنش، شريفى، خاص محمدى و كشاورز افشار، (9با). سبك تصميم گيرى افراد بيانخر الكوى عادتى است كه فرد به هنگام تصميم گيرى مورد استفاده قرار مىدهد. شيوههاى تصميم گيرى ثابت نبوده در طول زندگى قابل


تصميم گيرى عقلانى، شهودى، اجتنابى، آنى و وابسته را بر اساس ويثز گهاى شخصيتى و درونى افراد مطرح كردهاند. سبك تصميم گيـرى عقلانى، بيـانگر تمايسل فرد به شناسايى تمامى راهكارهاى ممكن، ارزيابى نتايج هر راهكار از تمامى جنبههـاى مختلـف و در نهايـت انتخاب راهكار بهينه و مطلوب است. تصميم گيرى شهودى بر اساس شهود و بدون طى مراحل فرايندى صورت مى گيرد. سبك تصميم گيرى وابسته بيانكر عدم استقلال 
(محمودى، بهمن يور و باسامى،

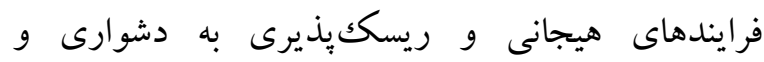
ييجيد گى تصميم گيرى مىافزايد. مطالعات نشان دادهاند


مخاطرات را كوجّكتر، شناخته شده تر و كنترليذيرتر ادراكك مى كنند و اين امر در تصميم گيرى آنها منعكس مىشود. براى مثال تحقيقات نشان داده هر خه ادراكك ريسك براى ابتلا به ايدز كاهش مىيابد نرخ شيوع ايدز

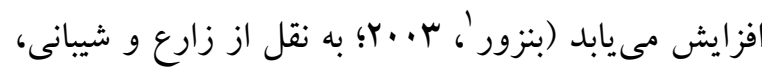

. (1rq.

با توجه به اهميت تصميم گيرى هاى دوره جوانى و مبتنى بر اين مفروضه كه مكانيسمهاى مشتركى براى تصميم كيرى و كاركردهاى اجرايى وجود دارد و ريسك بـدئي و كاركردهاى اجرايى از جمله ويز گیىهاى مؤثر بر سبك هاى تصميم گيرى هستند، تحقيق حاضر به بررسى نقش

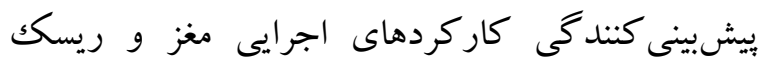
يذيرى در سبكهاى تصميم گيرى دانشجويان برداخته

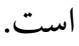

روش يثزوشش حاضر از نوع توصيفى - همبستكى است. جامعه آمارى اين بثروهش را كليه دانشجويان كارشناسى ارشد (دختر و يسر) دانشگاه آزاد اسلامى واحد كرمانشاه كه در سال تحصيلى Q\-QV مشغول به تحصيل بودند تشكيل مىدهد. تعداد كل اين جامعه •VD نفر بودند. از اين


جدول مورگان و به روش نمونه گيرى خوشهاى جندمر حلهاى انتخاب شده و مورد آزمون قرار كر فتند. به
اجرايى مىتواند در فرايند (تحليل و انتخاب مؤلفهها) و سبك تصميم گيرى افراد به عنوان مكانيسمهاى عصبشناختى زيربنايى دخيل باشند (نجاتى، rar|). به عنوان مثال تحقيقات نشان داده مديرانى كه سبك تصميم گيرى منطقى دارند توجه دقيق و هشيارانهترى نسبت به محيط و تغييرات آن داشته، بهتر مىتوانند عواطف و احساسات خود و ديخران را شناسايى كنند (بهرامى، سوسا). زارع و محمدى (هوبا) نيز معتقدند بين ناتوانى در شناسايى هيجانات و سبك تصميم گيرى اجتنابى رابطه وجود دارد. مشكلات موجود در تشخيص و تمايز احساسات خود و شناخت اجتماعى، فرد را مستعد بههمريختكى هيجانى در روابط يا موقعيتهاى استرسزا كرده منجر به بروز

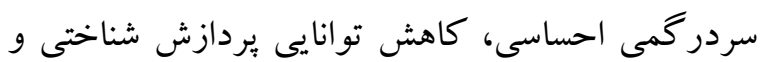
اجتناب از تصميم گيرى مى گردد (زارع و محمدى،

.$(1+90$

هر دورهاى از زندگى منبع تصميمات خاصى است. دوران دانشجويى را دوران رسيدن به استقلال مجدد مى دانند كه تحت تأثير آن، دانشجويان خودمختارى بيشترى در سبك زندكى و رفتارهاى خود احساس مى كنند. در اين دوره جوانان با موقعيت هاى جديد و گوناكونى (مانند فعاليتهاى نو، آينده كارى، الكل، مواد مخدر و...) مواجه شده، مجبورند در خصوص آنها تصميم گيرى نمايند. انتخاب برخى تصميمات نيازمند فرايند تفكر منطقى و برخى نيز نيازمند قدرى جسارت است. از سويى ديخر جوانى سن هيجانطلبى است. هيجان خو اهى مىتواند بر رفتار، ويثز ها و اولويتهاى انتخابى افراد اثر داشته

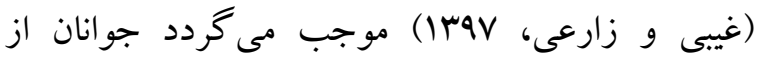
ريسك يذيرى بالاترى برخوردار باشند. تحقيقات نشان داده ميزان ريسك يذيرى دانشجويان، متوسط به بالا است 
سبك هاى شخصيت در اين برسشنامه ه سؤال اختصاص داده شده است. به هر سؤال بر اساس يكك مقياس

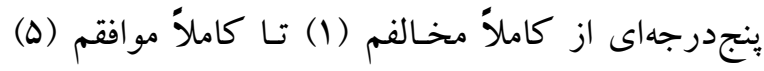



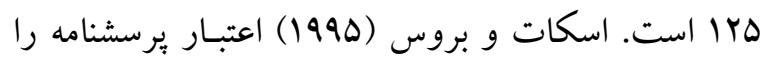

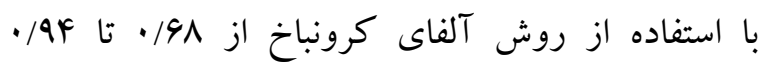
كزارش كرده اند. در ايران زارع و شيبانى (•وسا) مقدار اعتبار برسشنامه را از طريق ضريب آلفاى كرونباخ ND/ •، باز آزمايى با فاصله F هفته 191 • و براى روش فرم موازى ضريب همبستخى VD/ • به دست آوردهاند. روايى محتواى بيرسشنامه توسط متخصصان روانشناسى تأييد شده است (ابو القاسمى، كريمى و خشنودنياى، هوبا(). در بثزوهش حاضر اعتبار اين يرسشنامة با روش آلفاى كرونبـاخ NF/ • بـه دسـت آمـد.

يرسشنامه كاركودهاى اجرايی: اين :برسشنامه توسط نجاتى (rar|) جهت سنجش توانايىهاى شناختى افراد

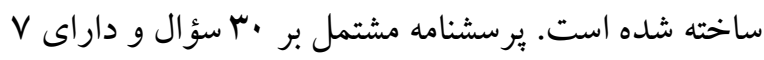
خرده مقياس است. در اين ئوهش از خرده مقياسهاى حافظه فعال، كنترل مهارى (بازدارى) و توجه انتخابى،

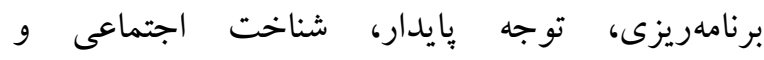
انعطاف بذيرى شناختى استفاده شده است. سؤالات در قالب مقياس ليكرت ينج گزينه اي (تقريباً هركز، بهندرت، كاهى اوقات، اغلب و تقريباً هميشه) پِاسخ داده مىشود و هر سؤال نمرهاى بين يكك تا بنج خواهد كرفت. به اين ترتيب كمترين و بيشترين نمره قابل دستيابى به

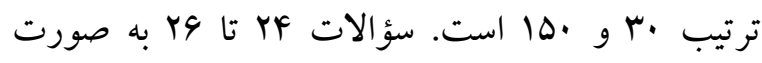
معكوس نمره گذارى مىشوند. نجاتى ضريب اعتبار يرسشنامه را به روش آلفاى كرونباخ شی/ • و همبستخى ييرسون دو نوبت اجراى آن در سـطح 1+٪ • معنـادار ذكر
اين ترتيب كه ابتدا از بين دانشكدههاى دانشگاه آزاد اسلامى واحد كرمانشاه به تصادف دو دانشكده (ادبيات و حقوق) و سبّ از بين كلاسهاى هر دانشكده به تصادف F كلاس انتخاب شد. متوسط اعضا هر كلاس وب نفر بود، اما در كل تعداد rDG نفر همكارى نمودند. عمدهترين ملاكك ورود به نمونه تحقيق دانشجوى مقطع كارشناسى ارشد بودن و نداشتن سابقه اختلال روانيزشكى بود. عدم رضايت از مشاركت در يُوهش و ناتوانى در تكميل برسشنامهها به دليل مشكلات جسمى از جمله ملاككهاى خروج از مطالعه بود. شيوه اجراى يزوهش به اين ترتيب بود كه با همكارى دفتر برنامهريزى كلاسى و كسب اجازه از اساتيد، در كلاس حاضر شده برسشنامهاى يزوهش بين دانشجويان توزيع گرديد. در مورد نحوه تكميل يرسشنامهها توضيحات لازم از سوى بزوهشخر ارائه شد. دانشجويان بس از اعلام رضايت جهت شركت در ئزوهش و اطمينان از اينكه اطلاعات آنها محرمانه باقى خواهد ماند، اقدام به تكميل برسشنامهها نمودند. در نهايت يس از جمع آورى يرسشنامهها و حذف يرسشنامه هاى ناقص • Y. برسشنامه قابل استفاده به دست

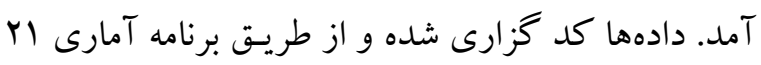
spss متغيرهاى موردنظر از يرسشنامهاى سبككهاى تصميم كيرى، كار كردهاى اجر ايى و ريسك يذيرى استفاده شد.

ابزار يرسشنامه سبكهاى تصميمريرى: اين برسشنامه توسط اسكات و بروس در سال 1990 ساخته شده، ينج سبك






برسشنامه را با استفاده از آلفاى كرونباخ بو/· • و روايى سازه آن را بس/· ذكر كرده است (مرادى، جعفرى، قاسمى، صادقى و حيدرى، سهبا). در يزوهش حاضر

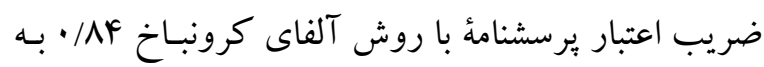
دسـت Tمـد.

\section{يافتهها}

اين ئزوهش بر روى . ب. ب. دانشجوى مقطع كارشناسى

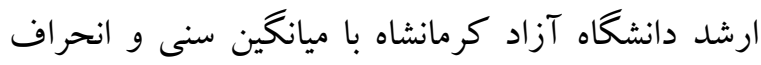

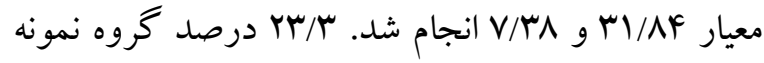
متأهل و V9/V درصد مجرد بودند. ميانگين و انحراف معيار متغيرهاى ئزوهش و نتايج آزمون كلموگروف اسميرنف جهت بررسى نرمال بودن توزيع آنها در جدول شماره ا درج گرديده است.
كرده است. نتايج تحليل عامل اكتشافى نيز روايى همه عوامل آزمون را مورد تائيد قرار داده است (نجاتى، لتهيل

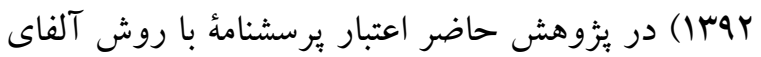

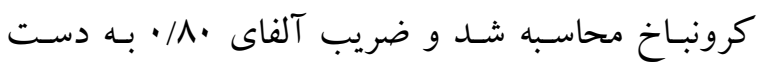

يرسشنامه ريسك يذيرى: اين يرسشنامه توسط احمديور

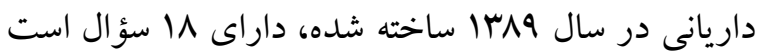
كه در قالب طيف ليكرت جهار ززينهاى ( كاملاً مخالفم" تا "كاملاً موافقم" پِاسخ داده مىشود. سؤالات اين برسشنامه تمايل فرد براى ريسك كردن و خطريذيرى را برحسب يكك مقياس ليكرت جهار درجه ای مىسنجد.

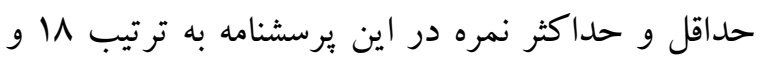

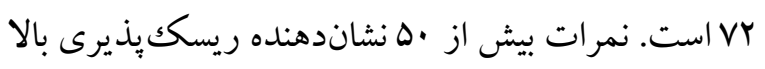
در فرد است. احمديور داريانى ضريب اعتبار اين

جدول ا ميانكين و انحر اف معيار و نتايج آزمون كلموكروف-اسميرنف متغيرهاى بثروهش

\begin{tabular}{|c|c|c|c|c|c|c|}
\hline معنادارى سطح & k-s & انحر اف معيار & ميانكين & تعداد & مؤلفه & متغير \\
\hline - MFG & . /arb & T/MY & $19 / 11$ & rF. & منطقى & \multirow{5}{*}{ سبك هاى تصميم تيرى } \\
\hline$\cdot / \cdot \wedge f$ & $1 / r \Delta Q$ & r/rIF & $I V / r$ & rF. & شهودى & \\
\hline$\cdot / 4 \cdot 1$ & - /A9F & r/VoV & $\mid \Delta / \cdot 1$ & rF. & و ابسته & \\
\hline$\cdot / 4 \cdot r$ & . / Aq & $r / F r l$ & $11 / 94$ & rF. & آنى & \\
\hline$\cdot / 119$ & $1 / 194$ & $r / 941$ & $11 / \wedge \Delta$ & rF. & 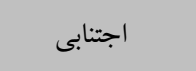 & \\
\hline . & $1 / 190$ & $Q / Y \Delta \Delta$ & $\kappa \varphi / 94$ & rF. & & ريسك يذيرى \\
\hline$\cdot / \cdot v 1$ & $1 / \% 91$ & $r / 919$ & rD/FG & rF. & حافظه & \multirow{6}{*}{ كار كردهاى اجرايى } \\
\hline$\cdot / r \cdot 1$ & $1 / \cdot v r$ & $r / 9 r 1$ & $r Y / A V$ & rF. & بازدارى & \\
\hline$\cdot \pi \cdot v$ & $|/ r|$. & T/YIQ & $11 / v 9$ & rF. & برنامهريزى & \\
\hline$\cdot / r \Delta \Delta$ & $1 / \cdot 1 f$ & r/YYY & $1 \cdot / \Delta \Delta$ & rF. & تو جه بايدار & \\
\hline.$/ \cdot \Delta V$ & $1 / 9 M$ & $r / Y \cdot G$ & $1 \cdot / v$ & rF. & شناخت اجتماعى & \\
\hline.$/ \Delta F$ & $1 /$ TKF & r/VYr & $10 / 49$ & rF. & انعطاف بذيرى & \\
\hline
\end{tabular}


اسميرنوف نيز نشان داد تمام مؤلفها از توزيع نرمال برخوردار بودند. نتايج ضريب همبستخى بيرسون بين

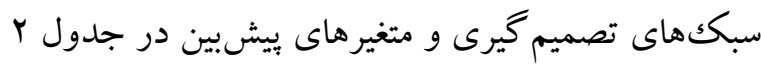

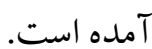

همان كونه كه جدول ا نشان مى هده سبك تصميم گيرى

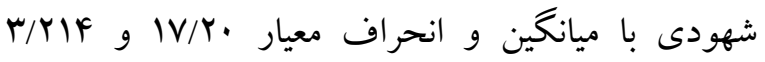
بيشترين و سبك تصميم گيرى اجتنابى با ميانكين و انحراف معيار 11/1ه و استفاده توسط دانشجويان بود. آزمون كالمو گروف-

\begin{tabular}{|c|c|c|c|c|c|}
\hline اجتنابى & آنى & وابسته & شهودى & منطقى & \\
\hline$-\cdot / 4 r 9$ 光米 & $-\cdot /$ YFY 米光 & $-\cdot / 1 \Lambda$ * & .1 .90 & - / r FA米米 & حافظه فعال \\
\hline 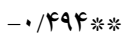 & $-\cdot / 1 V 9$ & - • & ( & .1 .94 & بازدارى \\
\hline$-\cdot / \Delta 1 Y * * *$ & $-\cdot / r V r_{*} * *$ &  &.$/ .91$ & $\cdot / Y Y F_{*}$ & برنامهريزى \\
\hline$-\cdot / \pi q_{*}$ & $-\cdot / \mathrm{TV}$ &.$- / 194$ & $\cdot / \cdot \wedge$ & $\cdot / Y 1 Q *$ & توجه يايدار \\
\hline$-\cdot / \cdot r \mid$ & $\cdot 11 \cdot 9$ &.$/ 11 r$ & •/FAץ兼米 & $\cdot / r \Delta F$ 光米 & شناخت اجتماعى \\
\hline$-\cdot / \Delta \& q_{*}{ }^{*}{ }^{\prime}$ & $-\cdot / r \curlyvee 9$ 米米 & $-\cdot /$ YYG 米米 &.$/ 189$ & $\cdot / T \cdot \Delta *$ & انعطاف يذيرى \\
\hline.$/ \cdot 1$ & $\cdot / T V F_{\text {彞 }}$ & $-\cdot / \cdot r V$ & .1 .99 & $-\cdot / \cdot .4$ & ريسك يذيرى \\
\hline
\end{tabular}

$* \operatorname{sig}<\cdot / \cdot \Delta * * \operatorname{sig}<\cdot / \cdot 1 \mathrm{~N}=r \digamma$.

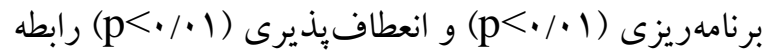

منفى و معنادار دارند. ريسك يذيرى فقط با تصميم گيرى آنى (1/p> p ) رابطه مثبت و معنادار داشت. به منظور بررسى مهمترين عامل از بين مؤلفههاى كاركرد اجرايى و ريسك يذيرى در بيشبينى سبكهاى تصميم گيرى از تحليل رگرسيون گامبه گام استفاده شد. نتايج تحليل رگرسيونهاى انجام شده در جدول r نشان داده شده
يافتهاى جدول Y نشان مىدهد سبك تصميم گيرى

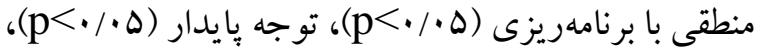

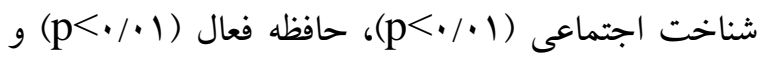
انعطاف بذيرى (ه// با شناخت اجتماعى (1/ > p) رابطه مثبت و معنادار دارند. در حالى كه سبكهاى تصميم گيرى وابسته و

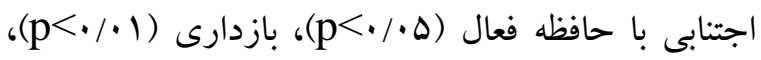

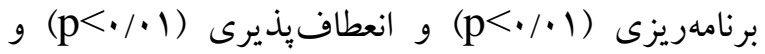
سبك تصميم گيرى آنى با حافظه فعال (1) (1)

جدول ץ تحليل ركرسيون براى بيشيينى سبكهاى تصميم تيرى بر اساس ريسك يذيرى و كار كردهاى اجر ايى

\begin{tabular}{|c|c|c|c|c|c|c|c|c|}
\hline \multirow{2}{*}{$\mathbf{R}^{2}$} & \multirow{2}{*}{$\mathbf{R}$} & \multirow{2}{*}{$\mathbf{P}$} & \multirow{2}{*}{$\mathbf{t}$} & \multirow{2}{*}{ بتا } & \multicolumn{2}{|c|}{ ضرايب غير استاندارد } & متغير بيش بين & \multirow[t]{2}{*}{ متغير ملاك } \\
\hline & & & & & انحراف استاندارد & B & & \\
\hline
\end{tabular}




\begin{tabular}{|c|c|c|c|c|c|c|c|c|}
\hline.$/ 1 Y G$ & $\cdot / r \Delta F$ & $\cdot / \cdots$ & $G / A \cdot V$ & $\cdot /$ TAG & $\cdot / \cdot V F$ & $\cdot / 0 \cdot 4$ & شناخت اجتماعى & \multirow{4}{*}{ سبكى تصميم كيرى } \\
\hline$\cdot /$ IVG &.$/ 419$ & $\cdot / \cdots$ & G/IVF & $\cdot / \mu M$ &.$/ 0$ & $/ r \cdot q$ & حافظه فعال & \\
\hline$\cdot$ / YYY & $\cdot / 01 Y$ & $\cdot / \cdots$ & $r / 90 \mathrm{~V}$ & $\cdot /$ MrF & • & $\cdot / \mu \cdot r$ & برنامه ريزى & \\
\hline$\cdot /$ YAG & . & $\cdot / \cdot \Delta$ & $Y / \wedge \Delta I$ &.$/ 194$ & $\cdot / \cdot V r$ & $\cdot / r \cdot 4$ & انعطاف يذيرى & \\
\hline . / YMF & - /FAF & $\cdot / \cdots$ & N/DYA & - /FAF & . & $\cdot / v \cdot \Delta$ & شناخت اجتماعى & سبكى تصميم كيرى \\
\hline $.11 \cdot 9$ & . TYG & $\cdot / \cdots$ & $-r / 911$ & $-\cdot / r \Delta r$ & $\cdot / \cdot v 1$ & $-\cdot / r \Delta 9$ & انعطاف يذيرى & سبكى تصميم كيرى \\
\hline$\cdot / l \Delta V$ & $\cdot / 41$ & $\cdot / \cdot r$ & $-Y / Q \wedge F$ & $-\cdot / r \cdot V$ & $\cdot / \Delta r$ & $-\cdot / 1 \Delta \Lambda$ & بازدارى & وابسته \\
\hline.$/ 1 F$ & $\cdot / M V F$ & $\cdot / \cdots$ & $9 / .49$ & $\cdot / M F \Delta$ & $\cdot|\cdot r|$ &.$/ M Y A$ & ريسك يذيرى & \multirow{3}{*}{ 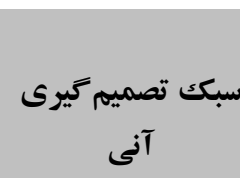 } \\
\hline$\cdot / Y Y \mid$ & $\cdot / F V$ & $\cdot / \cdot r$ & $-r / I F r$ & $-\cdot / r \cdot 4$ & $\cdot / \cdot \wedge r$ & $-\cdot / r \Delta Q$ & انعطاف يذيرى & \\
\hline . MFY & - /far &.$/ \cdot 1 r$ & $-Y / \Delta Y F$ & $-\cdot / 194$ & $\cdot / 1 \cdots$ & $-\cdot / r \Delta r$ & برنامه ريزى & \\
\hline$\cdot / r \cdot r$ & $\cdot / \Delta F q$ & $\cdot / \cdot \cdot 1$ & $-r / F A I$ & $-\cdot$ /rYG & $\cdot / \cdot \wedge \mathrm{V}$ & $-\cdot / r \cdot r$ & انعطاف يذيرى & \multirow{5}{*}{ سبكى تصميم كيرى } \\
\hline$\cdot / r v q$ & .1919 &.$/ \cdots$ & $-F / \mu I F$ &.$- / T F D$ &.$/ .94$ & $-\cdot / 4 \cdot r$ & برنامه ريزى & \\
\hline$\cdot / 41 \Lambda$ &.$/ 9 F V$ &.$/ \cdot r$ & $-r / A V Y$ & $-\cdot / \mathrm{Vrr}$ & .1 .9 & $-\cdot / I V r$ & بازدارى & \\
\hline . / Fr & .1994 & $\cdot / \cdot \cdot 1$ & $-r / 4 q$. &.$- / 19 V$ & $\cdot / \cdot \Delta V$ &.$- / 199$ & حافظه فعال & \\
\hline$\cdot / F F A$ & .1999 & $\cdot / \cdot \mu_{1}$ & $-r / 199$ &.$- / 11 V$ & $\cdot / \cdot \wedge \Lambda$ &.$- / 191$ & توجه پيايدار & \\
\hline
\end{tabular}

معنادار FF/A درصد سبك تصميم گيرى اجتنابى

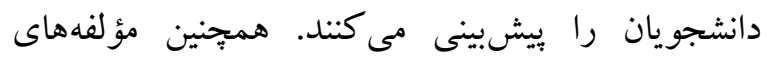
انعطاف يذيرى ( توان بيش بينى منفى و معنادار سبكك تصميم كيرى آنى را دارند. متغير ريسك يذيرى فقط توانايى بيشبينى مثبت و معنادار سبك تصميم گيرى آنى دانشجويان (1) ( راشت.

\section{بحث}

هدف از اين يثزوهش بررسى نقش كاركردهاى اجرايى و ريسك يذيرى در سبكهاى تصميم گيرى دانشجويان دانشخاه آزاد كرمانشاه بود. نتايج يزوهش نشان داد سبك

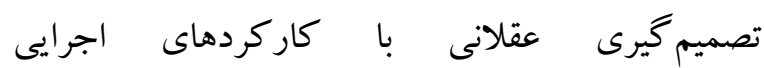
انعطاف يذيرى، برنامهريزى، توجه بيايدار، حافظه و شناخت اجتماعى رابطه مثبت معنادارى دارد. اين نتايج با
مطابق با جدول م، ضرايب رگرسيونى نشان داد مؤلفههاى

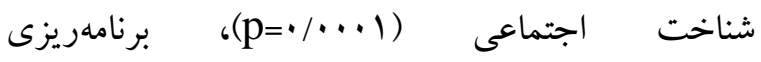
( ) (

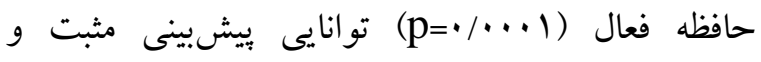
معنادار سبكك تصميم گيرى منطقى دانشجويان را دارند. در كل اين متغيرها YN/90 درصد اين سبك تصميم گيرى را بيشبينى مى كنند. بازدارى (

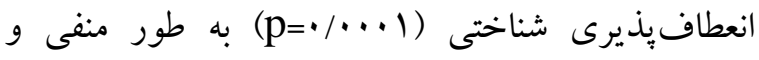
معنادار ه/V سبكك تصميم كيرى وابسته را در دانشجويان بيشبينى مى كنند. از بين مؤلفههاى كار كردهاى اجرايى فقط شناخت اجتماعى (1) ( تصميم گيرى شهودى نقش مثبت و معنادار داشت. كاركردهاى اجرايى انعطافيذيرى (

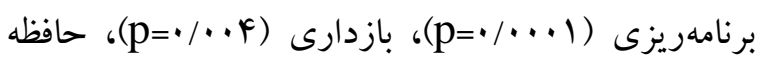

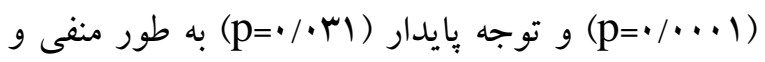


باشد نواحى بيشترى از لوب فرونتال را در گير مىسازد.

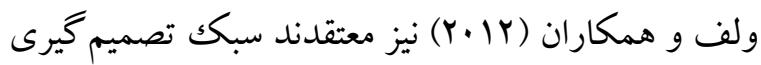
عقلانى با كاركرد اجرايى قشر خلفى -جانبى لوب فرونتال قابل تبيين است، زيرا فرايندى شناختى و خطى است كه شامل سه مرحله شناسايى درست مشكل، جستجوى كزينهاى ممكن و انتخاب مناسب ترين گزينه و اقدام در جهت اجراى آن است (ولف، واگت، وركايك،، هافه،

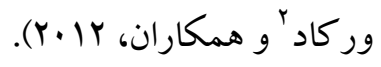

ديخر يافته هاى يُزوهش نشان داد از بين متغيرهاى بيش بين تنها شناخت اجتماعى توان بيش بينى سبك تصميم

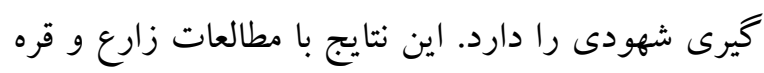

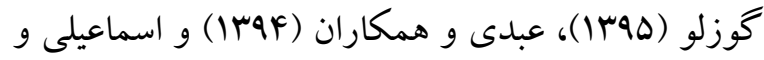
زارعى (سهץ|) همسو است. در سبك تصميم گيرى شهودى، در عين اطمينان به تصميم، روند دانستن و دريافت اطلاعات مشخص نيست (ديجيكسترا، يليكت،

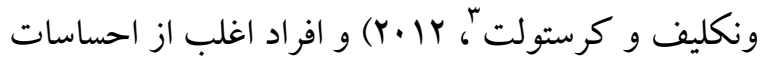
و عواطف درونى خود براى اتخاذ تصميمات شهودى بهره مى گيرند. تحقيقات حاكى از آن است بين دشوارى در تشخيص احساسات خود و ديخران (الكسى تايميا) با نهرهي سبك تصميم گيرى شهودى رابطه منفى و معنادارى وجود دارد (زارع و قره گوزلو، ههبا). از سويى ديخر افزايش هوش هيجانى باعث افزايش استفاده از شيوه

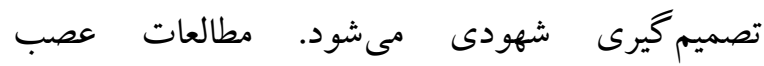
روانشناختى نيز نشان دادهاند مدار جشمى يِيشانى قشر يرهفرونتال در بردازشهاى هيجانى و شناخت و رفتار اجتماعى مناسب دخيل است (اسماعيلى و زارعى،

. (1rar
يافتهاى رستم اوغلى و همكاران (rا.ب)، ولف و

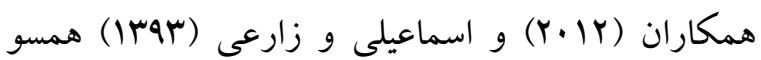
است. در تبين اين نتيجه مىتوان كفت فرايند تصميم گيرى شامل جندين مرحله است كه هر مرحله آن نيازمند فرايندهاى بايهاى شناختى خاصى است. درك و و شناسايى مشكل به عنوان اولين مرحله از فرايند تصميم گيرى مستلزم توجه دقيق و متمركز بر مسئله، براى شناسايى جوانب آن است. تهيه فهرستى از گزينه آناى ممكن براى انتخاب، نيازمند بازخوانى موارد مرتبط به

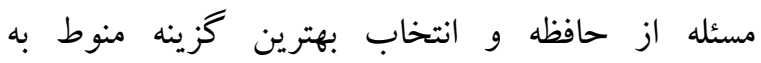
برنامهريزى و شناخت درست گزينها است. آخرين مرحله از فرايند تصميم گيرى شامل اجراى تصميم و ولرئ ارزيابى نتايج حاصل از اجراى راه حل منتخب نيز مستلزم انعطاف لازم براى بازنخرى در برنامه به هنگام برخورد با موانع و خطاها و توانايى تغيير احتمالى راه حلهاست. از سويى ديخر تحقيقات نشان داده افرادى كه از توانايى ذهنى بيشتر براى يردازش اطلاعات اجتماعى و حفظ توجه مستمر بر فرايند تصميم گيرى برخوردارند، درك لرك بهترى از فرايند و بيامدهاى فعاليتهاى رفتارى و تصميم كيرى خود داشته، موفق تر عمل مى كنند و در نتيجه فشار


شوند (رستم اوغلى و همكاران، سا •r). تحقيقات عصب-شناختى نيز نشان داده كاركردهاى اجرايى فرايندهايى مرتبط به لوب فرونتال بهويزه ناحيه يرهفرونتال مىباشند (ليريس'، 19 19). تصميم گيرى نيز

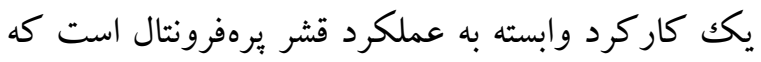
بسته به نوع سبكك تصميم گيرى مىتواند به بخشهاى

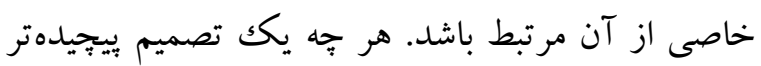

2- Wolfs, Vugt, Verkaaik, Haufe \& Verkade

3 - Dijkstra, Pligt, Kleef \& Kerstholt
${ }^{1}$ - Liris 
آنى و ماجر اجويانه مبتنى بر هيجاناند و نمىتوان آنها را بر بايه منطق حاكم بر عملكردهاى اجرايى همجيون توجه پايدار و برنامهريزى تبيين كرد (نجاتى، بوسا). در سبكك

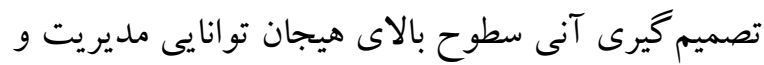
برنامهريزى و كنترل تكانه ها را محدود ساخته موجب مى شود افراد بدون بشتوانه فكرى كامل و در كمترين

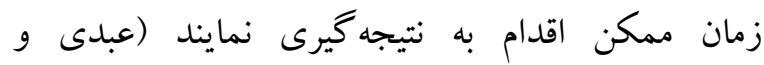

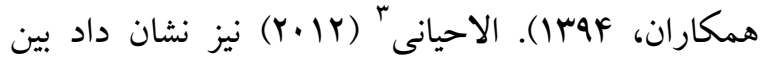
سبك تصميم گيرى آنى و ناهماهنگى شناختى و و آنى برانكيختخى حاصل از آن رابطه مثبت وجود دارد. نتيجه ديخر اين بثوهش مبنى بر اين كه انعطاف يذيرى و

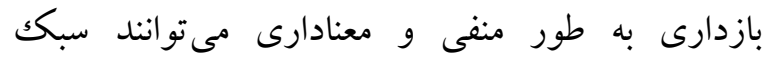

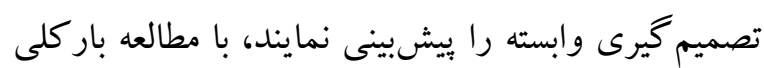

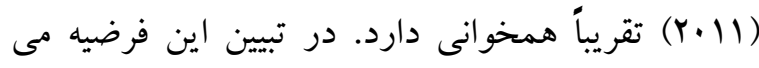
توان كفت افراد وابسته جون تصميم گيرى را خارج از توان و كنترل خود مى دانند در تصميم گيرى نقش منفعل

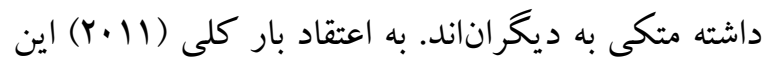
مسئله با الكوى بازدارى قابل تبيين است. مطابق اين الكو، آسيب در بازدارى، جهار كاركرد اجرايى اساسى شامل بل بال

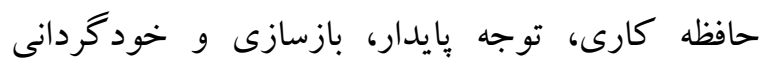
هيجانى را تحت تأثير قرار داده، موجب آسيب به به بـان خود كنترلى و ناتو انى فرد در تصميم گيرى مى شود.

\section{نتيجه كيرى}

به طور خلاصه يافته هاى يثوهش حاضر نشان داد كه سبككهاى تصميم گيرى با كاركردهاى اجرايى و ميزان يترون


تصميم گيرى كاركردهاى اجر ايى متفاوتى دخيل است. از
غالباً افرادى كه نسبت به توانايىهاى خود شناخت يا اعتماد كافى ندارند از اتخاذ تصميم مىهر اسند. مطالعات نشان داده افرادى كه به شناخت ها و هيجانات خود آكاهى آسى ندارند و نمى تواند از كاركردهاى اجرايى درست استفاده كنند، به احتمال بيشتر دجار شكك و ترديد شده، از

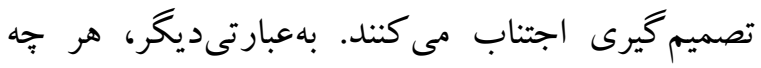
آكاهى فرد از انديشهها و فرايندهاى فكرى خود بيشتر باشد بهتر و زودتر مىتواند موقعيتهاى گوناكون را تحليل كرده، رفتار مناسب را بيش كيرد و كمتر احتمال دارد در تصميم گيرى خود تعلل كند. از سويى ديخر اجتناب و طفره رفتن از تصميم گيرى نيز، توانايىهاى شناختى را تحليل برده مانع يردازش درست اطلاعات مىشود، اين امر احتمال بيامدهاى نامطلوب را افزايش دهد (عباسى، ييرانى، درگاهى و آقاويردى نزاد، سهبر).

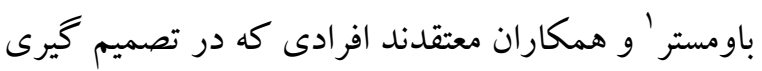
مشكل دارند براى رهايى از تنش و هيجانات منفى و ايجاد احساس بهتر در خود دست به تعلل يا اجتناب

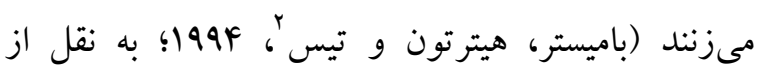
عباسى و همكاران، سوسا). اين امر تائيد كننده يافتهاى اين يُزوهش مبنى بر ارتباط منفى و معنادار سبك تصميم گيرى اجتنابى با مؤلفهاى كار كرد اجر ايى است. يافته يزوهش حاكى از آن است كه دانشجويان با سبك تصميم گيرى آنى از سطوح ريسكيذيرى بالاترى برخوردارند. همجنين ارتباط معكوسى بين تصميم گيرى آنى دانشجويان با انعطاف يذيرى و برنامهريزى به دست آمد. اين نتايج با مطالعات الاحيانى (Y (Y. (Y)، عبدى و

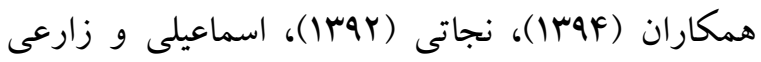
(سوسו) همسو است. نجاتى نشان داده تصميم گيرىهاى

\footnotetext{
1- Baumeister

2- Baumeister, Heatherton \& Tice
} 
University of Medical Sciences in 2014. Scientific-Research Quarterly of the Iranian Scientific Nursing Association, 4(3), 19-29. [In Persian]

Abolghasemi A, Seyedeh Haedeh Karimi SH, Khoshnoodnia B. (2017). Comparisons of self-regulation behavior, emotional selfawareness and decision making styles in women with and without generalized anxiety disorder. Psychological Studies, 12(4), 6-26. [In Persian]

Allahyani M. (2012). The Relationship between Cognitive Dissonance and Decision-Making Styles in a Sample of Female Students at the University of Umm Al Qura. Education, 132(3), 641-663.

Bahrami F. (2014). Investigating the Relationship between Awareness Mind Skills and Decision Making Styles of Malek Ashtar University of Technology. Scientific-Research Joumal of Management Improvement, 8(1), 840-849. [In Persian]

Barkley RA. (2011). Deficits in executive functioning scale(BDEFS). New York: Guilford Press.

Dijkstra KA, Van Der Pligt J, Van KleefGA, Kerstholt JH. (2012). Deliberation versus intuition: Global versus local processing in judgment and choice. Joumal of Experimental Social Psychology, 48(5), 1156-61.

Gheibi A, Zarei HA. (2018). Prediction of Internet addiction based on emotion seeking and identity styles in students. Shenakht Joumal of Psychology and Psychiatry. 5(3), 53-65. [In Persian]

Grunig R, Kuhn R. (2013). Rational Decision-Making. Successful Decision-Making. Springer, 23-31.

Hosseini FS, OmidvarY, Abbasi N. (2017). The role of executive functions and negative thoughts in explaining the difficulty in regulating the excitement of adolescents. Quarterly of Clinical Psychology Studies, 7(26), 83-111. [n Persian]

Ismaili S, Alizadeh Zarei M. (2014). Neural infrastructure, executive functions and its importance in education and rehabilitation.

$$
\begin{aligned}
& \text { آنجائى كه كسب مهارت در تصميم گيرى كارآمد } \\
& \text { موجب افزايش ظرفيت دانشجويان براى تطبيق با شرايط } \\
& \text { دشوار و مديريت تعارضها مى مردد، استفاده از } \\
& \text { برنامهاى آموزشى مناسب در جهت تقويت كاركردهاى } \\
& \text { شناختى و و تنظيم هيجان مىتواند به به افزايش } \\
& \text { تصميم گيرىهاى مناسب و كاهش تصميم گيرىهاى } \\
& \text { يرخطر دانشجويان كمك كند. از جمله محدوديتهاى } \\
& \text { اين يزوهش استفاده از يرسشنامه است. عدهاى از } \\
& \text { صاحبنظران علم روانشناسى، برسشنامهاى خود سنجى } \\
& \text { را ابزار تشخيصى معتبرى براى ارزيابى مهارتها و و } \\
& \text { مقولههاى روانى نمىدانند. اميد است در بزوهشهاى } \\
& \text { آتى، كاربرد ابزارهاى دقيقتر به غناى نتايج يثوهش }
\end{aligned}
$$



$$
\begin{aligned}
& \text { سياسگز ارى } \\
& \text { از تمامى دانشجويانى كه صبورانه يرسشنامهاى اين } \\
& \text { يثوهش را ياسخ داده و ما را در انجام اين يُزوهش يارى } \\
& \text { نمودند كمال تشكر را داريم. لازم به ذكر است بين } \\
& \text { نويسند گان هيج گونه تضاد منافعى وجود ندارد. اين } \\
& \text { يثزوهش برگرفته از پيايان نامه دانشجويى است و از } \\
& \text { حمايت مالى هيج موسسهاى برخوردار نبوده است. }
\end{aligned}
$$

\section{References}

Abbasi M, Pirani Z, Dargahi Sh. (2014). The relationship between cognitive impairment and emotional insufficiency by delaying decision making in students. Iranian Journal of Medical Education, 14(10), 905-915. [In Persian]

Abdi A, Assadi P, Mohammadyari T, Miri J. (2015). General decision-making style and clinical competence of nurses working in the educational hospitals affiliated to Kermanshah 
Exceptional Education, 14 (5), 37-44. [In Persian]

Jahanbakhshi Z, khoshkonesh A, khasmohamadi M, keshavarz afshar A. (2012). The Effectiveness of occupational Perpetrating Program with Group Method on making decision styles Female Students. Quarterly Joumal of Career \& Organizational Counseling, 4(12), 50-65. [n Persian]

Liris A. (2016). Executive functions in psychotic adults. Journal Psychiatry, 23(3), 12-21.

Locozi A. (2016). Effective factors in better performance in students with learning disability. Joumal of leaming, 23, 45-53.

Mahmoudi N, Bahmanpour H, Basami I. (2010). Investigating the factors affecting student risk. Journal of Applied Sociology, 21(38), 35-56. [n Persian]

Moradi H, Jafari P, Ghasemi M, Sadeghi S, Heydari H. (2014). Explain the relationship between motivation to progress, control center and creativity with creativity. Journal of Innovation and Creativity in the Humanities, 3(4), 165181.

Nejati V. (2013). Cognitive Abilities Questionnaire: Development and Evaluation of Psychometric Properties. Advances in Cognitive Science, 15(2), 11-18. [In Persian]

Nejati V. (2013b). The relationship between brain executive functions and high-risk decision making in students. Joumal of Behavioral Sciences Research, 11(4), 270-278. [In Persian]

Rostamoghli Z, Mosazade T, Rezazadeh B, Rostamoghli S. (2013). The role of procrastination, self-regulation and meta cognitive beliefs in predicting alexitimea and academic bumout in female high school students. Joumal of school psychology, 2(3), 180-188. [In Persian]

Vasilescu Cezar. (2011). Effective strategic decision making. Journal of Defense Resources Management, 1, 101-106.

Wolfs CA, de Vugt ME, Verkaaik M, Haufe M, Verkade PJ, et al. (2012). Rational decisionmaking about treatment and care in dementia:
A contradiction in terms? Patient education and counseling, 87(1), 43-8.

Zare H, Mohammad R. (2017). Alexithymia and Decision Making Styles: A study of the relation between both constructs in a Nonclinical Group. Neuropsychology, 2(2), 61-76. [In Prsian]

Zare H, Sheibani Kh. (2010). The impact of student risk perception on decision making. The first national conference on the findings of cognitive science in education. [In Persian]

Zare H. Qaree Quzlu RM. (2016). Decision Styles and Alexei Timeia: A study of the relationship between the two structures in a non-clinical group. Joumal of Psychological Neurology, 2(7), 61-75. 